Petro G. Kyriienko, $\mathrm{PhD}$, docent of Department of chemistry, ecology and expert technologies

e-mail: p.kirienko@khai.edu

Oleksandr V. Betin, $\mathrm{PhD}$, professor, Head of Department of chemistry, ecology and expert technologies

e-mail: o.betin@khai.edu

Natalia V. Kuznetsova, docent of Department of chemistry, ecology and expert technologies e-mail:n.kusnetsova@khai.edu

National Aerospace University “Kharkiv Aviation Institute”, Kharkiv, Ukraine

\title{
SMALL SEWAGE WASTEWATER TREATMENT PLANTS FOR DOMESTIC WASTEWATER
}

\begin{abstract}
Small sewage wastewater treatment plants are used for treatment of domestic wastewater from individual residential houses, small schools, roadside cafes, restaurants, small railway stations, camping sites, etc., where there is no centralized sewage network. In cases when there is a limited space for the installation of small-scale treatment facilities, authors suggest using of septic tanks and drainage wells. Sewage effluents are collected with gravity force, without using electricity. Usage of proposed constructions does not cause pollution of soils and underground water horizons. Sanitary environment is stable and predictable.

Keywords: small sewage wastewater treatment plants; sewerage; household waste water; biological treatment of sewage effluents; cleaning technology; construction of treatment facilities; septic tank; drainage field; filter well
\end{abstract}

\section{Introduction}

In developed countries, small-scale sewage treatment facilities (sometimes called local ones) are used for cleaning wastewater from small households, individual residential houses, small schools, roadside cafes, restaurants, etc., where there is no centralized sewage system.

Using small-scale treatment plants includes biological cleaning of domestic sewage in special facilities where natural treatment is modeled. Such facilities are compact, have small area footprint, may combine mechanical and biological treatment of waste water, treatment of sediment, cleansing and disinfection in a single block. This allows to locate them near drainage facilities, to reduce costs, to simplify operation and sanitary control. Their main features are that in many cases such treatment facilities are able to operate without energy resources (electricity), they are cheap compared with centralized sewerage network. The efficiency of domestic wastewater cleaning in small-sized wastewater treatment facilities is higher than in other types of treatment plants [1]. Ecological and sanitary conditions in the locations of small-scale treatment plants are fully manageable and predictable.

Technologically, in small-scale wastewater treatment plants, household sewage treatment is performed in two stages. Initially, the waste liquid enters the septic tank (a specially designed reservoir) where the primary cleaning of the waste water occurs 
in anaerobic conditions. Organic substances of animal and plant origin get into sewage water in the form of carbohydrates, fats and proteins, as well as in the form of products of life activities. Biochemical processes of the decomposition of organic substances occur without the access of oxygen, it leads to formation of fatty acids, followed by their decay into hydrogen, carbon dioxide, methane and other gases. At first stage level of treatment reaches $60-65 \%$.

The second stage - purification occurs in aerobic conditions. This stage is similar to the treatment of sewage in biofilters. Simultaneously with the oxidative processes, there are also reductive processes of denitrification, during them microbes consume oxygen in formed nitrogen compounds, releasing molecular nitrogen, which goes to the atmosphere. This explains the low level of nitrides and nitrates in purified sewage. Part of the nitrates formed in the process of biological oxidation of organic substances of sewage is assimilated by plants when they go into soil, and a part is denitrified. Nitrogen in nitrates can be used for growth (biosynthesis) of biofilm.

Both in technological and in constructive terms, small-scale wastewater treatment plants are two-component ones.

The first component is a septic tank in which household wastewater is collected. In the septic tank household wastewater should stay from three to five days. Subsequently, preliminary purified by $60-65 \%$ wastewaters go to an underground drainage field, a biofilter, a filter well, filter trenches, or other devices for final purification (95-98\%), depending on the conditions of purification.

Today, there are many varieties of septic tanks that are used in small-scale wastewater treatment structures.

Septics can be made of high-density polyethylene (see Fig. 1). Such septic tanks are used in conjunction with an underground drainage field.

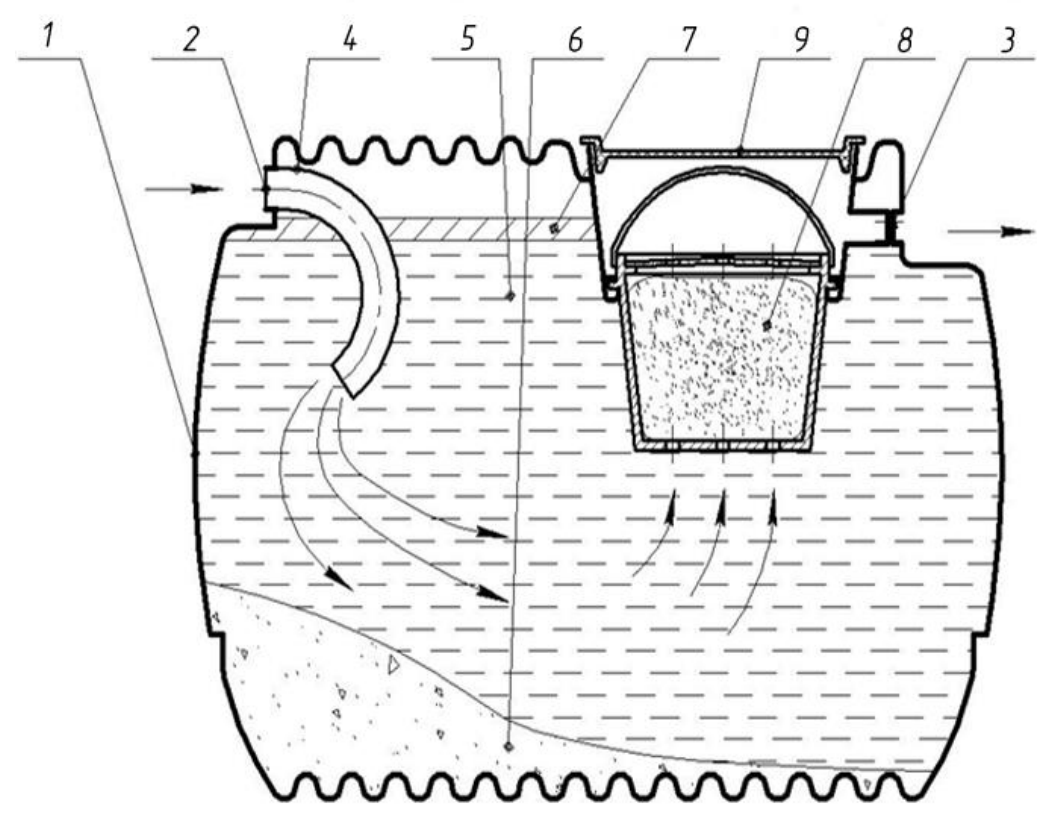

Fig. 1 - Septic. Design and principle of operation:

1 - body; 2 - entrance hole; 3 - outlet; 4 - deaerator hole;

5 - waste liquid; 6 - solid precipitate; 7 - layer of fatty substances; 8 - filter;

9 - hatch with lid 
Septics tanks can be made of different capacities. Table 1 shows volume of septic tanks depending the number of permanent residents.

Table 1 - Capacity of the septic tank and the equivalent number permanent residents

\begin{tabular}{|c|c|c|c|c|c|c|c|c|}
\hline $\begin{array}{c}\text { Number of } \\
\text { permanent } \\
\text { residents }\end{array}$ & 2 & 4 & $5-6$ & $7-8$ & $9-12$ & $20-25$ & $50-70$ & 120 \\
\hline $\begin{array}{c}\text { Capacity of } \\
\text { the septic } \\
\text { tank, liters }\end{array}$ & 1000 & 2000 & 3000 & 4000 & 5000 & 10000 & 20000 & 30000 \\
\hline
\end{tabular}

Septics can also be made of other materials, reinforced concrete, prefabricated concrete, bricks of special burning, rubble stone, etc., some specially designed tanks, different by volume.

Septics are located not far than $10 \mathrm{~m}$ and not closer than $3 \mathrm{~m}$ from the structure from which household wastewater is collected. If the septic is located more than $10 \mathrm{~m}$ away, it is necessary to take into account the climatic conditions (freezing of the soil). In this case, it is necessary to provide insulation of the sewer drain pipe. Purpose of septic tanks is preliminary cleaning of domestic sewage, provided that the sewage in the septic tank stays from 3 to 5 days.

The next degree of sewage treatment, which comes from the septic tank, is purification, it occurs in a drainage field. Section of its branch is represented in Fig. 2.

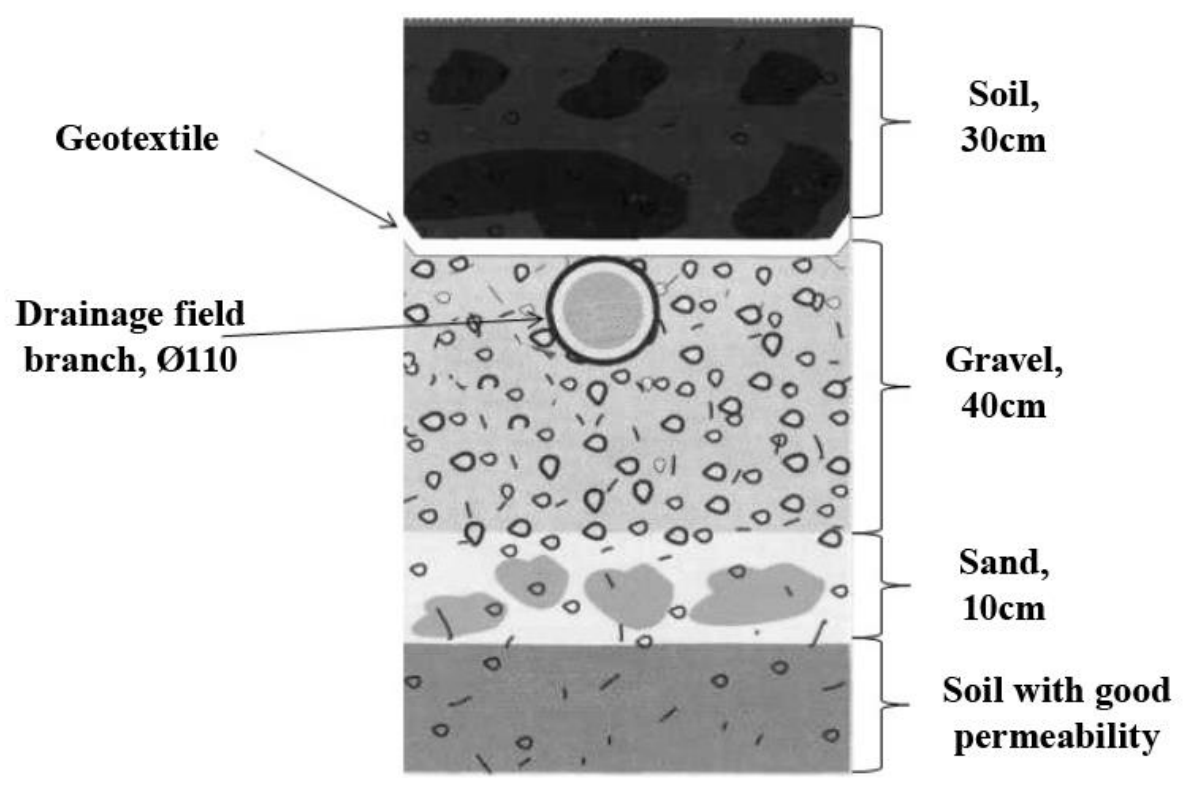

Fig. 2 - Section of drainage field branch

For the arrangement of wastewater treatment systems, it is necessary to take into account climatic conditions, soil permeability, surface ground water availability, etc. conditions. The internal sewage network is designed according to the wishes of the inhabitants. 


\section{Authors proposition}

Consider the simplest example of constructing an autonomous small-scale system for cleaning domestic wastewater.

An external sewage network serves for the removal of waste water from homes to small-scale wastewater treatment plants. For its installation, a pipe made of lowpressure polyethylene with a diameter of $110 \mathrm{~mm}$ is used (previously cast-iron, ceramic, asbestos-cement and other pipes were used). Sewage goes to wastewater treatment plants by gravity force. For this, the pipes of the external network should be laid with a slope of not less than $10 \mathrm{~mm}$ per one running meter of the sewer pipe.

The depth of the external network pipes is chosen taking into account the operation of the sewer network in the location of sewage. If such data are not available, then the smallest sewer pipe laying depth can be taken $300 \mathrm{~mm}$ lower than the maximum freezing depth of the soil, but not less than $700 \mathrm{~mm}$ from the top of the pipe to the zero planning mark.

The septic tank (Fig. 3) is a special reservoir of round or rectangular cross-section with waterproof walls and bottom. As a waterproof material, several layers of liquid glass or other waterproofing materials are used.

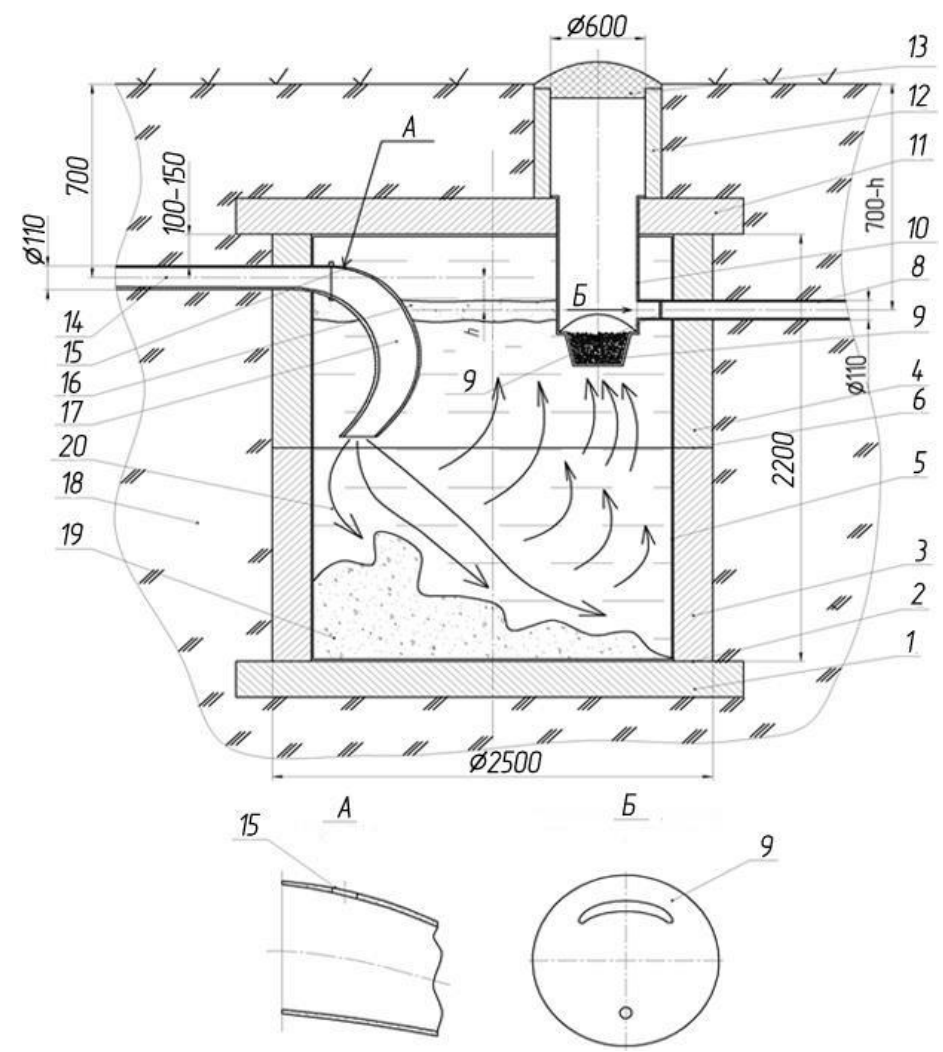

Fig. 3 - Septic:

1 - reinforced concrete slab; 2 - cement mortar; 3, 4- reinforced concrete rings; 5 - rubbing with a liquid glass; 6 - cement between rings; 7 - filter (a bucket with washed coke); 8 - outlet pipe; 9 - calibrated valve; 10 - filter housing; 11 - concrete slab ceiling of the septic tank; 12 - overlay; 13 - hatch; 14 - inlet pipe; 15 - decompression hole;

16 - foam of fatty substances; 17 - deflector; 18 - soil; 19 - solid precipitate; 20 - fluid streams 
The septic tank is equipped with an insert with a hatch for removing insoluble precipitate, which is collected at the bottom of the septic tank, inlet and outlet openings with pipelines, deflector, which is used to equalize the sewage flows into the septic tank, a filter with plastic body, mounted in the filter saddle (made in in the form of a bucket with holes in the bottom and filled with washed coke, or other filter material: claydite, slag, wood shavings), on which the suspension is delayed and lightening of the waste water is effected, a calibrated valve, for the dosed flow of lighted waste liquid into the filter well, as well as the normalized residence of the sewage in the septic tank.

Septic tanks can also be made of other materials, reinforced concrete, prefabricated concrete, bricks of special burning, rubble stone, etc., some specially designed tanks, different by volume. The top of the septic tank is covered with reinforced concrete slab with opening for mounting the overhead, inspection hatch, and filter housing. From above, overhead, reinforced concrete slab and the case of septic tank are covered with hydro-insulating material (bitumen, or a mixture of bitumen and diesel fuel in special proportions), than goes a layer of soil up to the top of the hatch, it is tucked down in form of soil slope from the hatch to all sides for the drainage for rain protection. At Fig. 3 sizes of septic tanks are indicated for a family of 5-6 permanent residents.

The inlet piece is equipped with a deflector. The deflector serves to equalize the flow of sewage in the septic, directed to the wall of the septic tank, in the upper part is located a decompression opening through which the gases formed in the septic tank are diverted.

The calibrated valve (Fig. 4, item 9) is made with a hole in the bottom, and in the upper part with a socket opening for adjusting the flow of lighted waste fluid into the filter well after a single large flow of water into the septic tank.

Sewage flows at a low speed (sewage water should be in the septic tank for 3 ... 5 days), it loses its suspended matter, or is lightened. The sediment in the septic tank can be stored for up to two years. During this period, the organic part of the sediment (silt) is decomposed by anaerobic bacteria. Insoluble organic matter is partially converted into gases, raise to the top of the septic tank, and removed through vents. Second part is converted into soluble mineral substances, and another part falls into the precipitate. Due to such processes, the amount of sediment is reduced by several times.

The calculation of septic tank begins with determining the number of permanent inhabitants in the buildings $-m$. Then the water flow rate per person per day in liters/day $-q$ is determined. Daily water consumption:

$$
q_{\text {daily }}=q \cdot m(\text { liters } / \text { day })
$$

The volume of septic tanks is determined from the condition of five days sewage treatment in septic tank. But the volume of the septic tank is not filled completely

$$
V_{\text {septic }}=q_{\text {daily }} 5 \text { (liters). }
$$

Then the estimated volume of the septic tank

$$
V_{\text {septic.est }}=V_{\text {septic }}+0,15 V_{\text {septic }}=1,15 V_{\text {septic }} \text {. }
$$


The value of $h$ (see Fig. 3 ) is determined from the condition of daily consumption of water $\left(\mathrm{m}^{3} /\right.$ day) by inhabitants

$$
h=q_{\text {daily }} / S
$$

where $S$ is the cross-sectional area of the treatment plant $\left(\mathrm{m}^{2}\right)$.

There is an empirical formula for calculating the volume of a septic tank from a condition: if the daily water consumption is up to $5 \mathrm{~m}^{3}$ per day, then the volume of the septic tank should be three times larger than the amount of wastewater per day:

$$
V_{\text {septic.est }}=3 \text { qdaily, }
$$

Sewage ventilation is performed due to the air space between the ceiling of the septic tank and the foam of the fatty substances that pops up to the surface of the sewage. Due to the fact that sewage does not flow to the septic tank continuously, but with some intervals, ventilation is carried out through a decompression opening, a sewage pipe, a riser of the internal sewage system, the open end of which goes in the form of a fan tube behind the roof of the building.

There are two-chambered septic tanks. Total volume is divided between first and second chamber as 0.75 and 0.25 of the total estimated volume of the septic tank. Such septic tanks are used to increase presence time of sewage in septic tank.

Septics are cleaned from silt once every two years. Silt is not removed completely, leaving up to $10 \%$ of the volume of sludge is good for better reproduction of bacteria performing process of decomposition of organic and mineral substances.

The filter is washed twice a year. A filtering bucket is removed. Filtering material is poured onto a polyethylene film and washed under a jet of water. Then loaded back into the bucket and set to a place. If a wooden chip is used as a filter material, then it is thrown into a compost pit and a new one is loaded into the filter.

Filter wells, underground filtration fields, sand-gravel filters and filter trenches are used for biological treatment of wastewater in small-scale treatment plants. Type of filtering structures is chosen depending on the filtering effectiveness and characteristics of soils, amount of sewage, availability of free place for their placement, risk of contamination of aquifers used for water supply, sanitary conditions of treated wastewater, etc.

Filter wells are the most simple and cheap wastewater treatment plants. But their area of use is limited. Wells can only be used with sand or sandy soils. On loamy soils, as well as in cracked rocks, filter wells are prohibited. The second point that limits the wide use of filter wells is their low productivity. They can be used in smallsized wastewater treatment plants with a volume of sewage up to $1 \ldots 1,5 \mathrm{~m}^{3} /$ day. (Fig. 4). If groundwater is used for household water supply, filter wells must be built at a distance of at least 30 meters from the water supply source.

Filter wells are made of reinforced concrete rings, special brick, rubble stone. Sizes of the filter well are given in Fig. 4 for 5-6 permanent residents. The walls and bottom of the wells are water permeable. To do this, at the bottom of the filter well, there are holes with a diameter of $20 \ldots 25 \mathrm{~mm}$ at a distance of $150 \mathrm{~mm}$ from each other. Under a filter well, there is a gravel bed with height of $400 \ldots 500 \mathrm{~mm}$. In the well, there is also a gravel layer with a height of $500 \mathrm{~mm}$, and outside the filter well, gravel is located within a ring of gravel with width of $400 \mathrm{~mm}$ up to position of drainage holes $(1 \mathrm{~m})$. As a filter material can be used gravel, crushed stone with a 
size of $30 \ldots 50 \mathrm{~mm}$, coke, slag. The top of the well is covered with a reinforced concrete slab with an overlay, a hatch with diameter of $600 \ldots 700 \mathrm{~mm}$ and a ventilation riser. To prevent the rainwater from entering the filter well, waterproofing the hatch, overlay, floor slabs and the upper part of the ring must be performed.

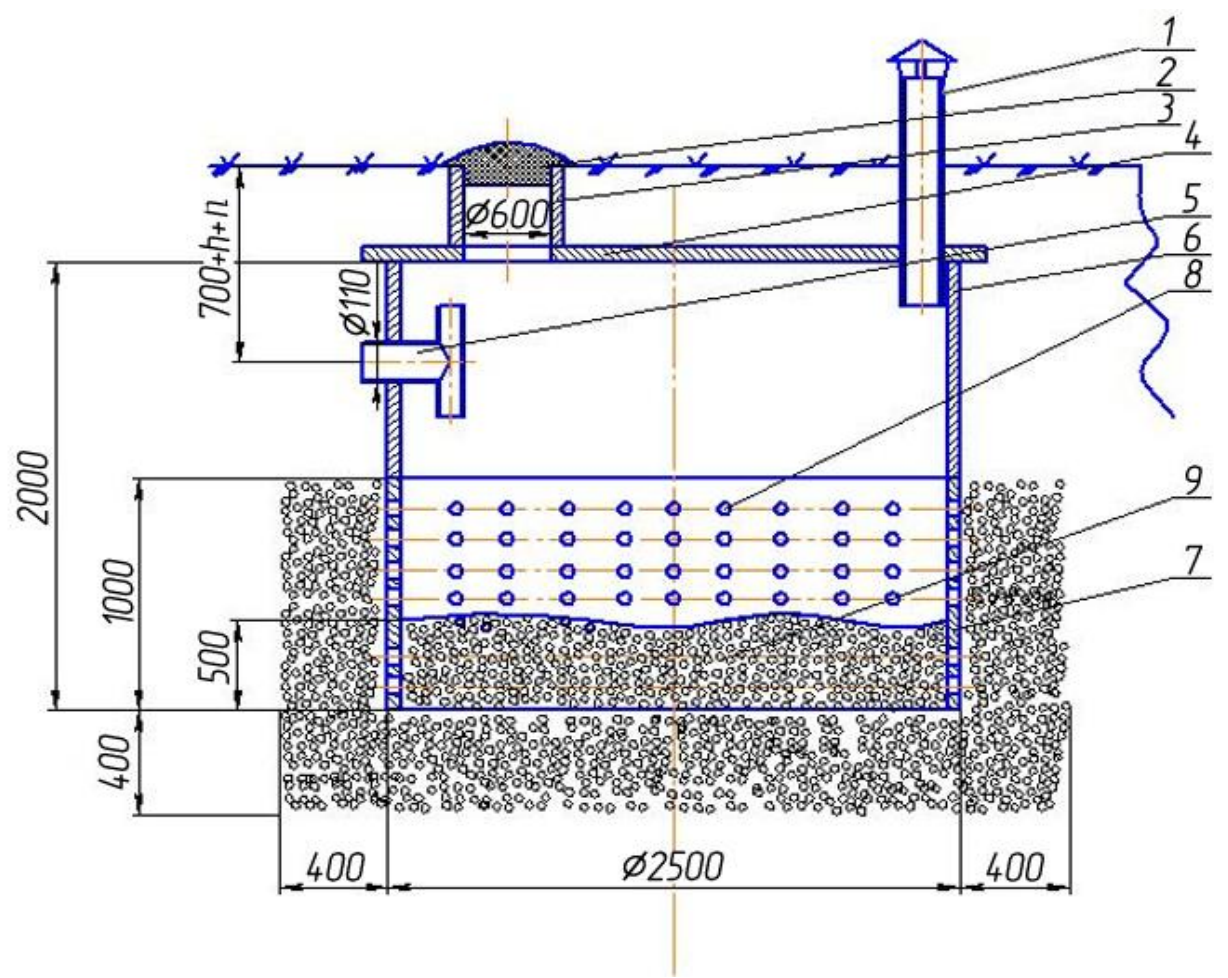

Fig. 4 - Filter well:

1 - ventilation riser; 2 - inspection hatch; 3 - overlay;

4 - reinforced concrete floor; 5 - drain device; 6, 7 - reinforced concrete rings;

8 - drainage holes; 9 - rubble

The value of $n$ (see Fig. 4) is determined from the condition of sewage self-flow from the septic tank to the filter well.

Filter wells are located at a distance of at least $30 \mathrm{~m}$ from the water intake.

\section{Conclusions}

Small-sized wastewater treatment plants can be autonomous without using electricity.

Using the proposed calculations and design decisions you can calculate and create a project for the sewage treatment for individual house.

Small-sized wastewater treatment plant is a few steps forward compared to the cesspool.

Sanitary situation in the locations of small-scale treatment plants meets the requirements of environmental safety. 


\section{REFERENCES}

1. Гончарук Е.И., Давиденко А.И., Каминский Я.М., Кигель М.Е., Полищук Ю.С. Малогабаритные очистные сооружения канализации. К.: “Будівельник”, 1974 - 256 с. 2. Голованова М.А., Кириенко П.Г., Варламов Е.Н. Экономическая эффективность применения автономной системы очистки канализационных стоков. VII міжнародна науково-практична конференція «Екологічна безпека: проблеми і шляхи вирішення». Том 2, С. 87-92, Харків - 2011.

3. Патент UA № 95720 від 25.08.2011, бюл. №16, МПК(2011.01) B01D 21/00, C02F 3/00, C02F 3/28 (2006.01), C02F 3/34 (2006.01), Септик для біологічного очищення побутових стічних вод, Кирієнко П.Г. та ін.

\section{REFERENCES (TRANSLATED AND TRANSLITERATED)}

1. Goncharuk, E. I., Davidenko, A. I., Kaminskij, Ja. M., Kigel, M. E., \& Polishhuk, Ju. S. (1974). Small sewage wastewater treatment plants for sewerage. Kyiv: Budivel'nyk (in Russian).

2. Golovanova, M. A., Kirienko, P. G., \& Varlamov, E. N. (2011). Jekonomicheskaja jeffektivnost' primenenija avtonomnoj sistemy ochistki kanalizacionnyh stokov. In VII mizhnarodna naukovo-praktichna konferencija "Ekologichna bezpeka: problemi $i$ shljahi virishennja” (pp. 87-92). Kharkiv (in Russian).

3. Kirienko, P. G. (2011). UA. Patent No. 95720. Septyk dlja biologichnogo ochyshhennja pobutovyh stichnyh vod. (in Ukrainian).

Text of the article was accepted by Editorial Team 20.06.2018

\section{П.Г. Киріснко, О.В. Бетін, Н.В. Кузнецова МАЛОГАБАРИТНІ ОЧИСНІ СПОРУДИ ОЧИЩЕННЯ ПОБУТОВИХ СТІЧНИХ ВОД}

Анотація. Малогабаритні очисні споруди каналізації використовуються для очищення побутових стічних вод від індивідуальних житлових будинків, невеликих шкіл, придорожніх кафе, ресторанів, невеликих залізничних станцій, кемпінгів та ін., де немає централізованої каналізаційної мережі. В тих випадках, коли бракує місця для розміщення малогабаритних очисних споруд, автори пропонують використовувати септики спеціальних конструкцій і дренажні колодязі. Запропоновані очисні споруди розташовують біля місць каналізування, але не ближче 3 метрів від споруди, для септиків. Дренажні колодязі розташовують на відстані від 2 до 3 м біля септиків. Каналізаційні стоки збираються будинковими каналізаційними мережами i самоплинно надходять в септик. Септики розраховуються на перебування стоків у ньому від 3 до 5 діб, а потім перетікають, фільтруючись через спеціальний фільтр, у дренажний колодязь. При цьому не використовується електроенергія. В дренажному колодязі стоки доочищаються і фільтруються в грунт. В екологічному відношенні біля очисних споруд, запропонованих авторами, не відбувається забруднення грунтів, підземних водних горизонтів. Санітарна обстановка стабільна і прогнозована.

Ключові слова: малогабаритні каналізаційні очисні споруди; каналізація; побутові стічні води; біологічне очищення стічних вод; технологія очищення; будівництво очисних споруд; септик; дренажний колодязь

\section{Киріснко Петро Григорович}

кандидат технічних наук, доцент кафедри хімії, екології та експертизних технологій, Національного аерокосмічного університету ім. М.Є. Жуковського "Харківський авіаційний інститут"

Адреса робоча: 61070 Україна, м. Харків, вул. Чкалова, 17

Тел: +380506194055 e-mail: p.kirienko@khai.edu 


\section{Бетін Олександр Володимирович}

доктор технічних наук, професор, завідувач кафедри хімії, екології та експертизних технологій Національного аерокосмічного університету ім. М.Є. Жуковського "Харківський авіаційний інститут"

Адреса робоча: 61070 Україна, м. Харків, вул. Чкалова, 17

Тел: +380679595683,e-mail: o.betin@khai.edu

\section{Кузнецова Наталія Володимирівна}

доцент кафедри хімії, екології та експертизних технологій Національного аерокосмічного університету ім. М.С. Жуковського "Харківський авіаційний інститут" Адреса робоча: 61070 Україна, м. Харків, вул. Чкалова, 17

Тел: +380675886580,e-mail: n.kusnetsova@khai.edu 